\title{
A NEW TYPE OF A LA TÈNE REIN GUIDE RING FROM VENDOLÍ (SVITAVY DISTRICT) AND ITS IMPORTANCE IN A REGIONAL AND SUPRA-REGIONAL CONTEXT
}

\author{
T O M Áš M A N GEL - D A V I D V ÍC H
}

\begin{abstract}
The article presents the find of a La Tène rein guide ring from Vendolí, Svitavy district. Morphological-typological analysis has shown that it was a so far unknown type dating to LTD1. From a regional point of view, the find complements the mosaic consisting of other, so far scarce La Tène artefacts discovered in the Svitavy region and along with them, it testifies to the existence of a communication corridor connecting permanently settled areas in eastern Bohemia and Moravia. In a supra-regional context, it represents a new hybrid form, combining features of certain western and eastern types of rein guide rings which constituted a functional and at the same time representative part of horse harness. Along with some similarly shaped finds, it represents a specific central European variant of these remarkable artefacts associated with the world of late La Tène social elites.
\end{abstract}

Keywords: Czech Republic, Svitavy region, La Tène Period, rein guide ring, communication corridor, social identity.

\section{INTRODUCTION}

Issues associated with horses and wagons have been the focus of intensive interest for a long time, especially in the context of cultural manifestations of the Hallstatt period. Over recent years, the above-mentioned topics have frequently also been addressed in connection with the La Tène period (e.g. Mírová 2019; 2020; Pieta 2008, 236-243; Schönfelder 2002, 131-327). One such topic are questions associated with the appearance and meaning of harness for draught animals. Evidence for it in archaeological sources is very scarce and, in most cases, it is represented by rein guide rings which were part of a wooden yoke. The importance of rein guide rings can be seen on two levels. Their practical function was to guide the rein guides and prevent them from becoming tangled (Schönfelder 2002, 224). On the other hand, such lavishly decorated and, in most cases strongly typified specimens also had a symbolic function. In this sense, it is possible to perceive La Tène rein guide rings as a materialized expression of the social identity of wagon owners who belonged to privileged social classes (Mangel/ Jošková/Krásný 2019, 41, 42).

Evidence for the existence of rein guide rings in Central Europe had until recently been very scarce, however, over recent years, mostly due to the intensive use of metal detectors in archaeology, their numbers have increased (summed up, e.g. in Čambal 2016, 128; Mangel/Jošková/Krásný 2019; Mírová 2019, 105-107, fig. 38; Pieta 2008, 237-239, 309, fig. 113;
Schönfelder 2002, 224-244, fig. 138-152; pl. 30-40; on new findings from Bohemia and Moravia: Mangel 2020, footnote 1). One of the very recent finds of this type is a rein guide ring found at Vendolí, Svitavy district (Czech Republic). This find not only extends the number of known rein guide rings, but it also enriches the range of known types, as it is an until now unknown shape. Thus, it allows us to open discussion about the typological development and importance of rein guide rings for our understanding of the late La Tène period.

\section{THE FIND SPOT AND FIND CIRCUMSTANCES}

The find was made with a metal detector by Tomáš Lusk, a collaborator of the Regional Museum in Vysoké Mýto on September $3^{\text {rd }}$, 2020. The finder immediately informed the museum's archaeological department. Thus, the find circumstances could be checked out by an archaeologist on the very same day, immediately after the discovery. The rein guide ring was found in the cadastral area of Vendolí, Svitavy district, at the location of 'Žlaby', which is situated ca $1900 \mathrm{~m}$ north from the centre of the village, at the southwestern edge of the Javornický ridge (Fig. 1; WGS84 coordinates: $49.756472^{\circ} \mathrm{N} ; 16.410286^{\circ} \mathrm{E}$ ). The find spot is located on a densely forested slope with an inclination of $24^{\circ}$, at $513 \mathrm{~m}$ a.s.l. No other artefacts were found in the surroundings, despite repeated metal detector surveys. 


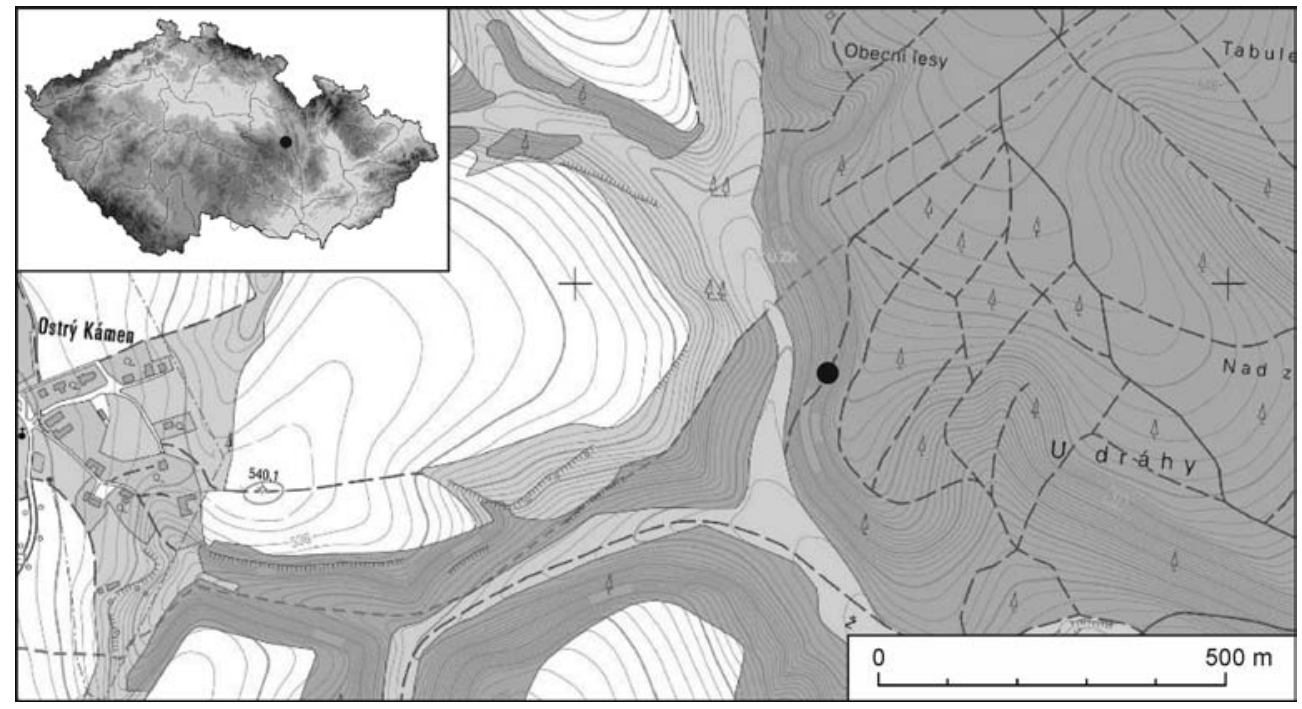

Fig. 1. Vendolí, Svitavy distr. The find spot of the rein guide ring is marked with a circle. Base map: ČÚZK.

\section{DESCRIPTION \\ AND TYPOLOGICAL-MORPHOLOGICAL ANALYSIS OF THE ARTEFACT}

The object is a cast bronze rein guide ring (Fig. 2) whose body contains a wide kidney-shaped eyelet in the upper part. The ends of the eyelet's body resembling volutes are attached to a prominent central bar so that two little hooks protrude from it towards the centre. In the downward direction, the central bar changes into a swollen neck decorated with a prominent bulge which is linked to a roughly square, arched fixing plate. On the bottom side of the plate, there is placed a round loop which originally served for attaching the ring to the base. The central part of the fixing plate is on both sides decorated with pairs of wedge-shaped thin embedded lines with centrally placed concentric circles. The total height of the object is $94 \mathrm{~mm}(87 \mathrm{~mm}$ without the loop), the dimensions of the fixing plate are $30 \times$ $35 \mathrm{~mm}$ and its thickness ranges between 3-4 mm. The outer dimensions of the kidney-shaped eyelet are $80 \times 58 \mathrm{~mm}$, while its inner width is $57 \mathrm{~mm}$. The object weights $230 \mathrm{~g}$. The surface parts of the object do not show any signs of wear, and except a minor bent in the attaching loop, no signs of mechanical damage are visible.

It is beyond doubt that the Vendolí find is a La Tène rein guide ring. This assumption is based on its general design and decoration. Certain problems are naturally connected with its clas-

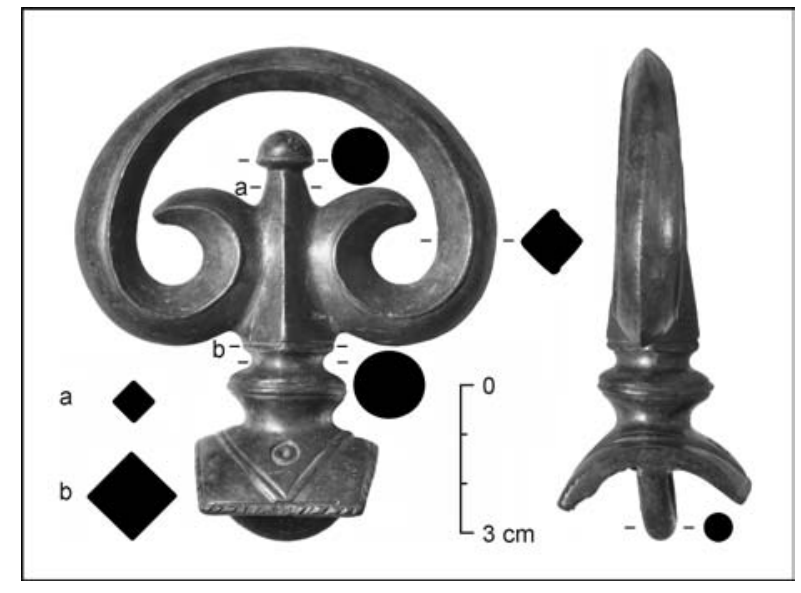

Fig. 2. Vendolí, Svitavy distr. Bronze rein guide ring (photo by T. Mangel).

sification, as there is no exact analogy for it among known finds. It is also not possible to ascribe it to any of the previously defined types (cf. Schönfelder 2002, 224-244). The wide, kidney-shaped eyelet with clearly separated ends decidedly points to the eastern La Tène Orešac type. ${ }^{1}$ From the viewpoint of classification, the hook-shaped ends of the eyelet also seem to be of great importance. An object with an indication of a similar termination was found at the Dacian site of Piatra Roşie in Romania - it is actually an Orešac type rein guide ring (Rustoiu/ Ferencz 2002, 231, fig. 1: 6). Another artefact whose fixing plate bears very similar decoration consisting

\footnotetext{
1 Characteristic features of Orešac type rein guide rings are a wide, kidney-shaped eyelet whose ends are distinctly separated by a relatively narrow neck, and a fixing plate which is decorated with embossed ribs on the sides (Schönfelder 2002, 236, fig. 145).
} 


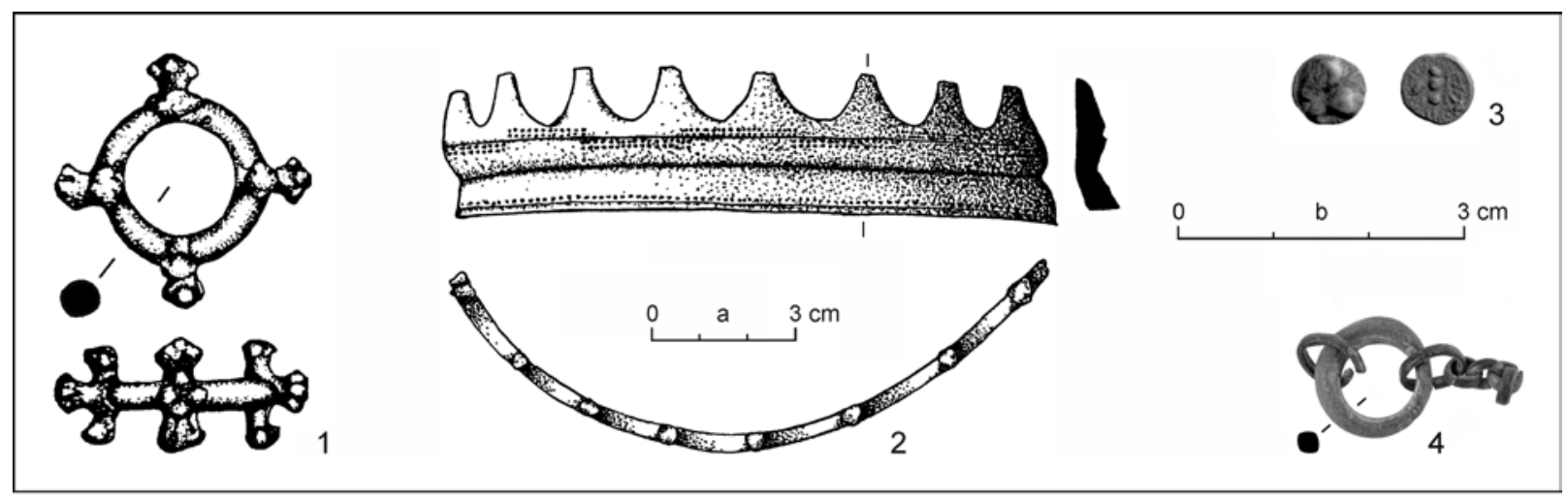

Fig. 3. La Tène finds from the Svitavy region. 1 - Čistá-Brlenka (Vích 2014, fig. 4: 7); 2 - Křenov (Vích 2017, fig. 18); 3 - Vendolí (Militký 2018, pl. 18: 65/1); 4 - Bělá nad Svitavou (photo by T. Mangel). Scale: a - 2; b - 1, 3, 4 .

of embedded concentric circles and wedge-shaped lines comes from the Carpathian Basin, from the site of Divici in Romania (Rustoiu/Ferencz 2002, 231, fig. 1: 7). On the other hand, the find in question differs from the Orešac type by the absence of characteristic ribs on both sides of the fixing plate and by the presence of an elongated central neck with a knob-shaped end which represents a sort of central bar. The presence of such a bar, as well as the character of the fixing plate and the overall proportions of the find point towards Hoppstädten type rings which are widespread in western and central Europe. Moreover, a specific variant of Hoppstädten type rein guide rings features hook-shaped projections coming out of the central bar (Mírová 2019, 107, pl. 58: 1). The assignment of the Vendolí find to this type is unfortunately impossible due to the different shape of the eyelet, as well as the way of attachment of the central bar to its body. ${ }^{2}$ Therefore, it seems reasonable to classify similar finds, where the eyelet's body is interrupted and its volute shaped ends are attached to the center bar on the sides, as the Vendolí type. The use of this hybrid form can be, probably similarly to both the abovementioned types, sought in the LTD stage (cf. Mírová 2019, 149, fig. 59). With regard to the fact that the La Tène cul- ture gradually died away in Bohemia and Moravia around the half of $1^{\text {th }} \mathrm{c}$. BC, this dating can be, such as in the case of other similar finds, narrowed down to the earlier part of the above stage, i.e. to LTD1 (Mangel/Jošková/Krásný 2019). ${ }^{3}$

\section{DISCUSSION}

The contribution of the discovery of the Vendoli rein guide ring can be seen both in a regional and supra-regional context. It was made in the eastern hilly part of the Svitavy Upland (Svitavská pahorkatina; Demek/Mackovčin 2006, 433), which is an archaeologically poor territory. This space actually makes up a contrasting transition between intensively settled areas in Bohemia in the west and in Moravia in the east (cf. Danielisová et al. 2018, fig. 37). Until recently no convincing evidence for any La Tène period activities had been known from there. Sporadic references in earlier literature are usually associated with finds and information which can be considered dubious. ${ }^{4}$ However, the above situation is gradually changing to the better. Thanks to metal detectors surveys in the Svitavy region over the last decade, it has been

\footnotetext{
2 The Hoppstädten type features a prominent closed circular eyelet and a central bar whose bottom saddle-shaped end is soldered to the eyelet. The eyelet is connected to the fixing plate, which is usually decorated with triangles, by a relatively thin neck (Schönfelder 2002, 239, 240, fig. 149).

3 The applied chronological concept for the end of the La Tène culture is based on the so-called south German chronology which presumes the decline of Bavarian, Bohemian and Moravian oppida during the LTD1b subphase (Fischer 1988; Waldhauser 1983).

4 These include: 1. an ambiguous mention of La Tène cremation graves(?) from Bělá nad Svitavou (Filip 1956, 392) which is probably linked to also ambiguously dated finds of pottery and iron tools known from the nearby village of Brněnec (Czerny 1907, 33, 34; Richter 1955, 142); 2. an alleged discovery of Celtic coins at Květná which was most probably a misunderstanding - the find has a connection with the so-called hoard from Plumlov and the misunderstanding stems from similar German eponyms (Květná/Blumenau and Plumlov/Plumenau/ Mährisch Blumenau: Skutil 1934, 16, footnote 15; 1947-1948, footnote 30); 3. a La Tène potsherd deposited without additional information about the find circumstances and find spot in the collection of the village school at Moravská Chrastová (Skutil 1947-1948, footnote 30); 4. a disc secondarily ground from a ceramic fragment which is deposited in the collection of the Municipal Museum and Gallery in Polička (inventory no. H1121) - unfortunately, no details about the find circumstances and find spot are available.
} 


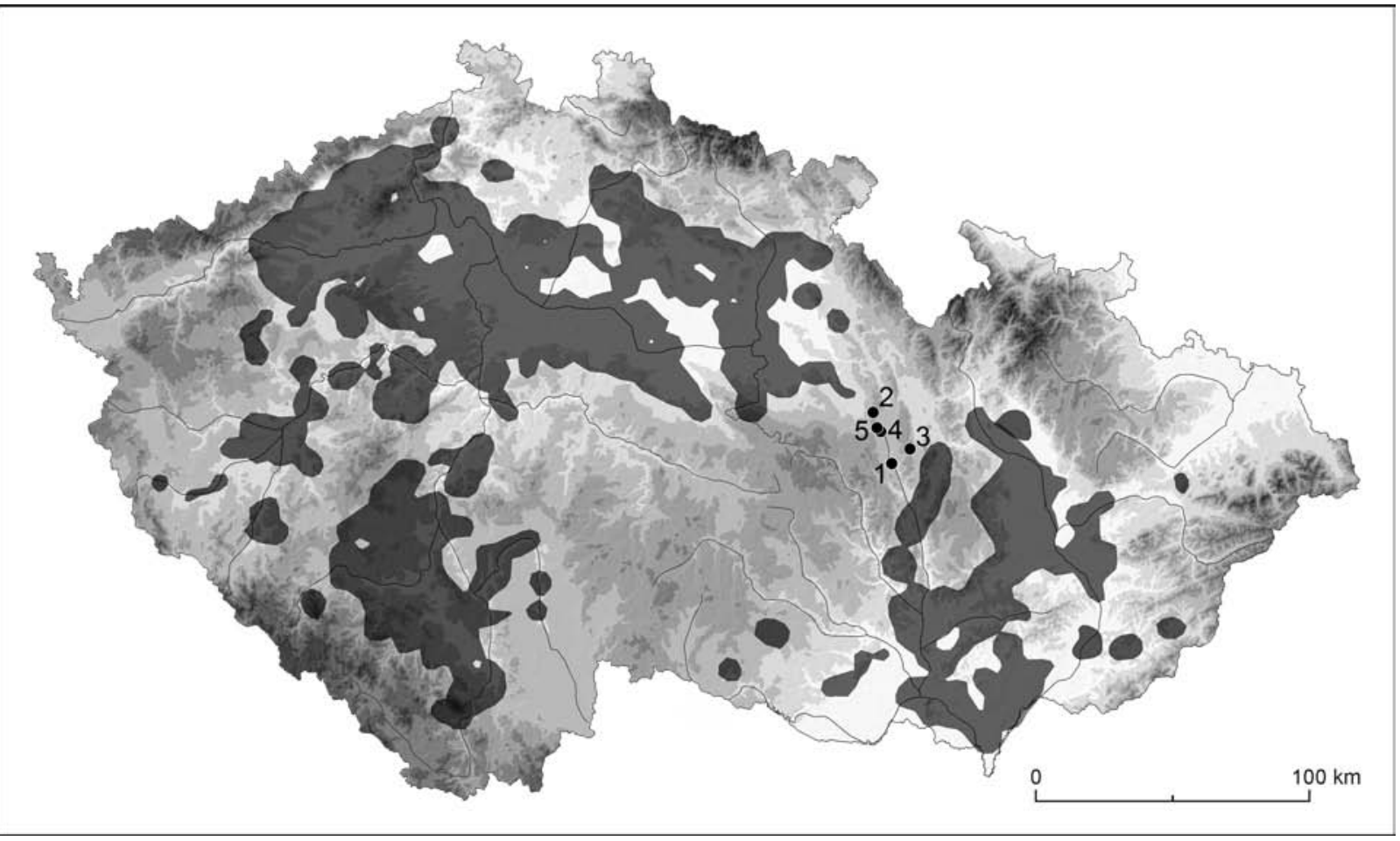

Fig. 4. La Tène finds from Svitavy region in the context of LTC-D1 settlement in Bohemia and Moravia. 1 - Bělá nad Svitavou; 2 - Čistá-Brlenka; 3 - Křenov; 4, 5 - Vendolí (base map after Danielisová et al. 2018, fig. 37; modified and complemented).

possible to register a small, but still important collection of artefacts dating back to late stages of the La Tène period. The earliest evidence for La Tène activities is a fragment of a bronze chain from Bělá nad Svitavou (Fig. 3: 4; 4: 1$)^{5}$ which probably originally formed part of a chain belt. The above artefact is only fragmentarily preserved, but it can most likely be attributed to the Gk-E1B group of bronze chain belts which chronologically belong to LTB2/C1-LTC1 (Bujna 2011, 87-89, 137, fig. 36; 59). Yet another La Tène find was also made in the cadastral area of Vendolí (Fig. 4: 4), just like the rein guide ring (Fig. 4: 5). It is a gold $1 / 8$ stater of the Athena Alkidemos type (Fig. 3: 3) which is a typical Celtic coin minted in the area of socalled corridor of the Amber road between Silesia and Lower Austria in LTC2 (Militký 2018, 285, 286, 357, pl. 18: 65/1). Near the village of Čistá-Brlenka, there was found a bronze so-called Knotenring (Fig. 3: 1; 4: 2; Vich 2014, 120, 126, 127, fig. 4: 7; 7) which can most probably be dated to LTC2-D1 (Dębiecl Karwowski 2016). A so-called Kronenhalsring found at Křenov is also dated to the La Tène period (Fig. 3: 2; 4: 3; Vich 2017, 644, 658, fig. 18). It is a foreign object originating from Jutland and the northern German zone of the Jastorf culture. Although finds of this ring-jewellery are practically unknown in the La Tène territory (except for pieces found at Nowa Cerekwia and Němčice nad Hanou: Rudnicki 2014,428 ), based on northern analogies, dating of the Kronenhalsring from Křenov to the period of LTC-D1 is unquestionable (Adler 2003, 274; Brandt 2001, 99, 100).

All these finds are isolated so they do not prove the existence of any permanent agrarian settlement in the local landscape. The type of landscape which is characteristic of the eastern part of the Svitavy Upland, was usually not very attractive for agriculture during the La Tène period (Holbová 2019; Venclová 2008, 23-28). An explanation for the presence of such finds therefore has to be sought in other areas of human activities, even though such a quest is quite complicated due to the nature of find circumstances. They do not enable us to reach an unequivocal decision whether these objects were unintentionally lost or intentionally buried in earth, as it is presumed e.g. in the case of isolated La Tène finds from the Bavarian-Bohemian border

\footnotetext{
5 The unpublished find of part of a belt was made by Milan Klačanský, a collaborator of the Regional Museum in Vysoké Mýto. With the exception of a Knotenring from Čistá-Brlenka which is kept in a private collection, all the other finds including the rein guide ring from Vendolí are the property of the Pardubice Region and are registered in the collections of the Regional Museum in Litomyšl.
} 


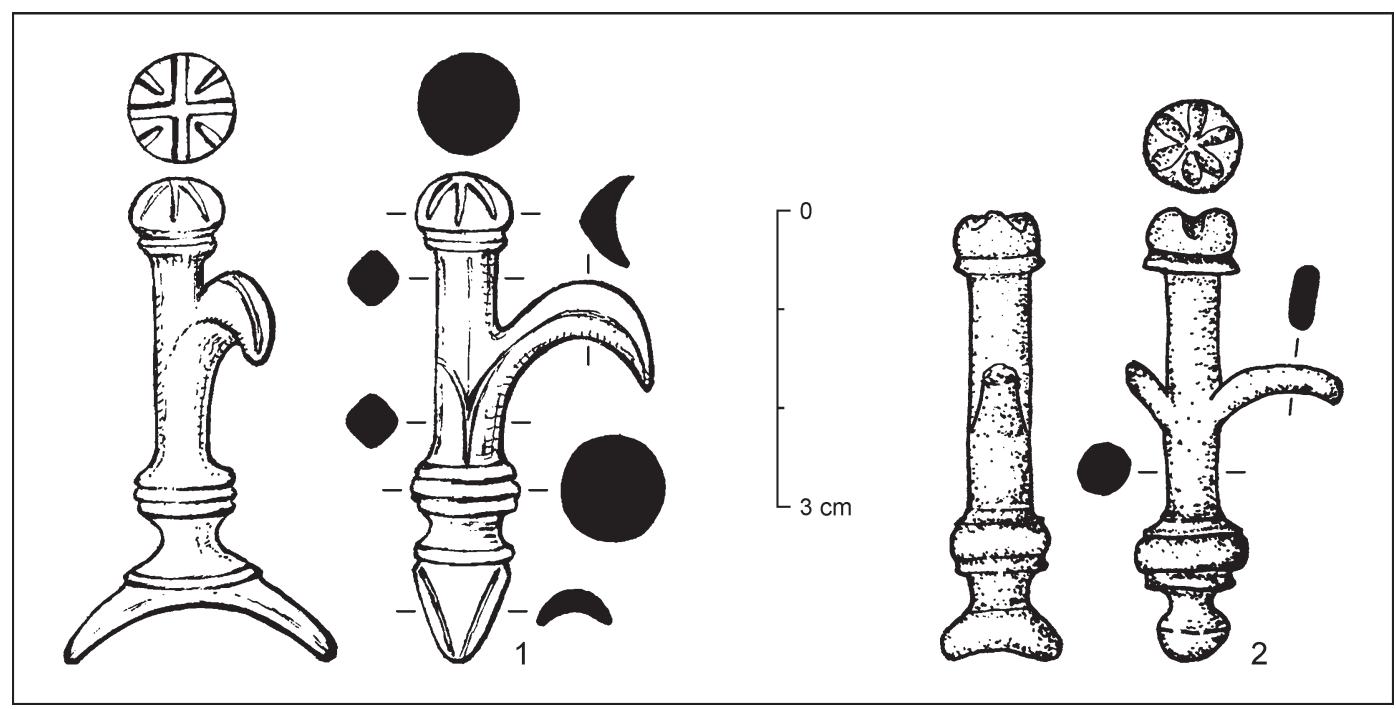

Fig. 5. Hoppstädten type rein guide rings, Malé Hradisko variant. 1 - Malé Hradisko, Prostějov distr. (Mírová 2019, pl. 58: 1a); 2 - Třísov, Český Krumlov distr. (drawing T. Kolegar and T. Jošková).

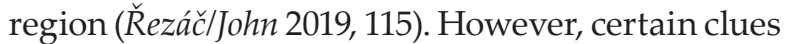
are available thanks to the spatial distribution of such finds (Fig. 4). On this basis, it is possible to consider their links, either direct or indirect, to a long-distance communication corridor connecting permanently settled areas in eastern Bohemia with populations living in southern and central Moravia. The existence of an alternative to such a corridor is also supposed, e.g. by J. Martínek and M. Golec for the Hallstatt period (Martínek/Golec 2020, 47, fig. 5). For the La Tène period, some kind of connection between these two regions is indirectly indicated by imports known from both sides of the imaginary border during LTB2 at the latest (e.g. Mangel/Jošková 2019). On the Bohemian side, evidence for La Tène settlement nearest to Vendolí (if we do not consider isolated finds) can be found at Tisová; a small ceramic collection dated with caution to the La Tène period is also known from Nedošín, ca $18 \mathrm{~km}$ away in the northeast direction (Vich 2003, 311, fig. 2: 9-11; pl. 3: 5, 6, 11-20). On the Moravian side, this is represented by several sites ca $25 \mathrm{~km}$ away in the northern part of the Boskovice Graben (Vích 2003, 313-317, fig. 3; pl. 5-16; 2017).

In order to fully understand the importance of the rein guide ring from Vendolí, it is necessary to look beyond the borders of Bohemia and Moravia and examine it in a broader context. As already mentioned, a noticeable feature of this type are its hook-shaped ends attaching to the sides of the central bar. In this respect, the find is not so unique. A similar design which is nevertheless undoubtedly derived from the Hoppstädten type was pointed out by Z. Mírová (2019, 107, pl. 58: 1) in context of a specimen from the oppidum of Malé Hradisko (Fig. 5: 1). She proposed to call this new shape the Malé Hradisko variant. Another, until now unpublished, specimen belonging to this variant was identified among a collection of finds from the south Bohemian oppidum of Tŕísov (Fig. 5: 2). ${ }^{6}$ Although the Vendolí ring distinctly differs from these finds in basic features (the shape of the eyelet, the way of attachment of the bar), certain partial similarities with the Malé Hradisko variant are apparent. All these cases have in common the existence of a central bar with hooks. In the current state of knowledge, the group of 'hooked' rein guide rings seems to be limited in number and its importance will have to be defined in the future. Despite this, the established facts allow us to form at least one hypothesis. All so far known finds of rein guide rings come from the territory of Bohemia and Moravia. These are areas where interactions (although of varying intensity) with both western and eastern La Tène zones took place. This phenomenon is apparent, for instance, from the directions from which Mediterranean imports reached these areas (Kysela 2014), from the composition of some coin assemblages (Militký 2015, 115-153), as well as from other categories of artefacts (e.g. Čižmář/Čižmářová/Meduna 2018, 40, 41; Dizdar 2015; 2020; Pierrevelcin 2012). In the case

\footnotetext{
6 The find is deposited in the South Bohemian Museum in České Budějovice under the inventory number A33867. The authors thank to D. Daněček for the information about this find, to J. Militký for permission to work with it and to P. Zavřel for providing it to them for analysis.
} 


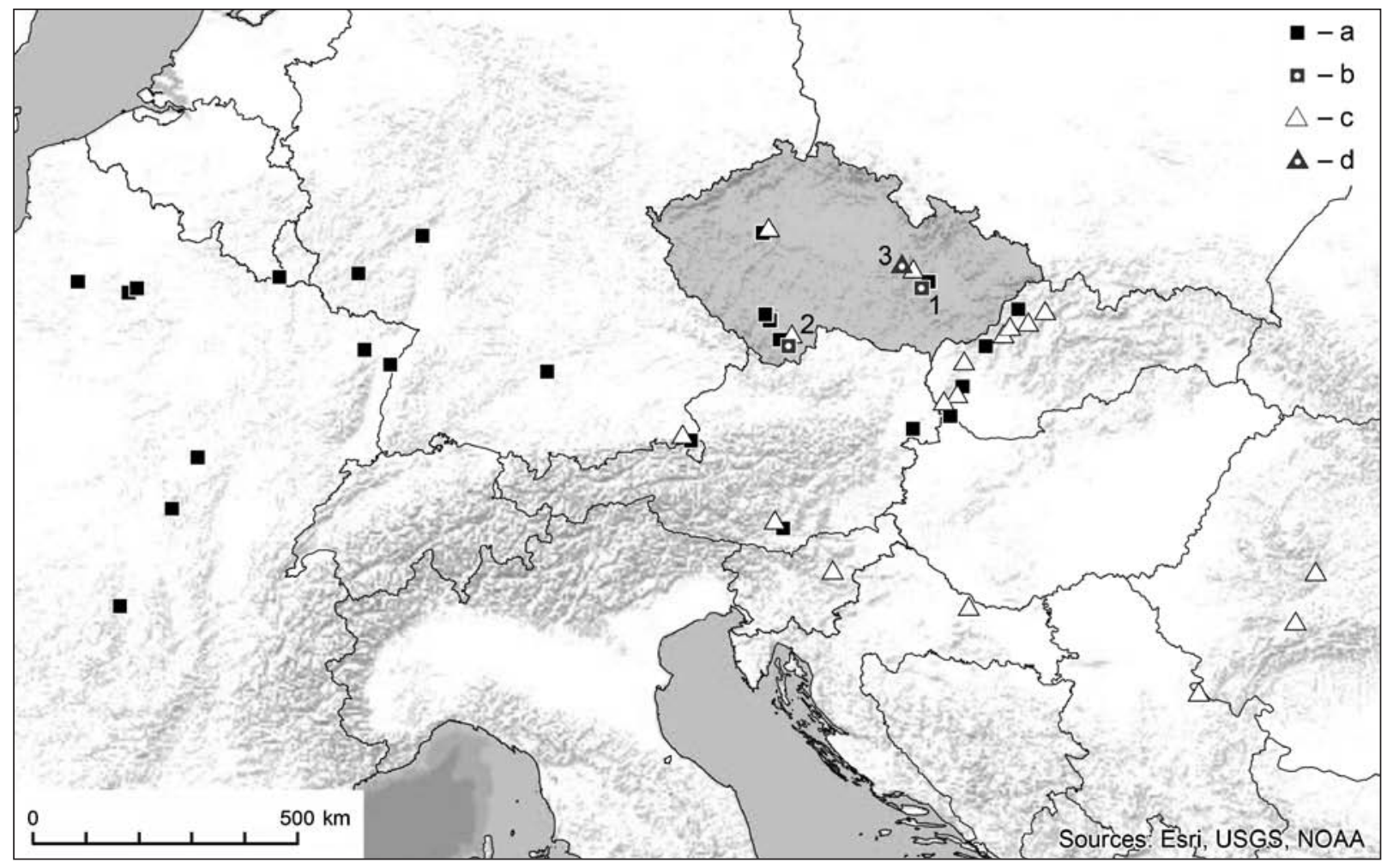

Fig. 6. Finds of rein guide rings with a central bar and inner hooks (Hoppstädten type, Malé Hradisko variant, and Vendolí type) in the context of distribution of the Hoppstädten and Orešac types. 1 - Malé Hradisko, Prostějov distr.; 2 - Tř́ísov, Český Krumlov distr.; 3 - Vendolí, Svitavy distr. Legend: a - Hoppstädten type; b - Hoppstädten type, Malé Hradisko variant; c - Orešac type; d - Vendolí type (compiled by T. Mangel).

of rein guide rings, this is also revealed by the distribution areas of western and eastern types. They seem to overlap in the area between the Ohře River and the Váh River (Mangel/Jošková/Krásný 2019, 40, 41, fig. 6). This fact can be demonstrated on the example of the distribution of the Hoppstädten and Orešac types (Fig. 6), while the 'hooked' rings show partial but convincing relations to these. Moreover, the shape specifics of both types meet in the appearance of the Vendolí rein guide ring. The rein guide rings of the Vendolí type and the Malé Hradisko variant most likely represent specific central European forms of these artefacts which are a result of influences from areas further west and east. In a social context, they can be understood as one of the specific manifestations of identity of central European elites of the late La Tène period.

\section{CONCLUSION}

The rein guide ring from Vendolí was recovered in the Bohemian and Moravian border region, from where only a few isolated La Tène finds are known. However, our knowledge about the dis- tribution of finds is changing and the amount of evidence testifying to use of this landscape during the La Tène period is gradually increasing. These activities, taking place in later stages of the above period, are most probably related to use of communication arteries connecting communities settled along the Moravian and east Bohemian parts of the imaginary border. The existence of such a connection is also indicated by finds of imports known from both areas.

The Vendolí find represents a so far unknown form of rein guide rings which in itself combines the properties of western and eastern types of this part of horse harness. It was these shape specifics that allowed us to define a new type of rein guide rings designated as the Vendolí type. Its use can most probably be dated to LTD1. Viewed from a broader perspective, the discussed object expands a scanty group of rein guide rings, which have in common the presence of a central bar with side hooks. Rein guide rings bearing these formal features seem to be specific central European shapes of these functional decorations and symbolic items which are a manifestation from the world of high social classes of La Tène society. 


\section{BIBLIOGRAPHY}

Adler 2003 - W. Adler: Der Halsring von Männern und Göttern. Schriftquellen, bildliche Darstellungen und Halsringfunde aus West-, Mittel- und Nordeuropa zwischen Hallstatt- und Völkerwanderungszeit. Bonn 2003.

Brandt 2001 - J. Brandt: Jastorf und Latène. Kultureller Austausch und seine Auswirkungen auf soziopolitische Entwicklungen in der vorrömischen Eisenzeit. Internationale Archäologie 66. Rahden/Westf. 2001.

Bujna 2011 - J. Bujna: Opasky ženského odevu z doby laténskej. Nitra 2011.

Čambal 2016 - R. Čambal: Spätlatènezeitliche Jochendbeschläge aus dem Gebiet von Bratislava. Zborník SNM 110. Archeológia 26, 2016, 125-132.

Čižmář/Čižmářrová/Meduna 2018-M. Čižmář/J. Čižmářová/ J. Meduna: Němčice a Staré Hradisko. Spony - Němčice und Staré Hradisko. Fibeln. Brno 2018.

Čižmářová/Venclová/Březinová 2014 - J. Čižmářová/N. Venclová/G. Březinová (eds.): Moravské křrižovatky. Střední Podunaji mezi pravěkem a historií. Brno 2014.

Czerny 1907 - A. Czerny: Aus grauer Vorzeit. Mitteilungen zur Volkskunde des Schönhengster Landes 3, 1907, 23-46.

Danielisová et al. 2018 - A. Danielisová/M. Chytráček/ J. Kysela/P. Sankot: Pět staletí keltské civilizace v Čechách. In: J. Militký/J. Kysela/M. Tisucká (eds.): Keltové. Čechy v 8. až 1. století před Kristem. Praha 2018, 64-91.

Dębiec/Karwowski 2016 - M. Dębiec/M. Karwowski: A Typological Study of the La Tène Knotenringe in the Territory of the Boii. In: M. Karwowski/P. C. Ramsl (eds.): Boii - Taurisci. Proceedings of the International Seminar, Oberleis-Klement, June $14^{\text {th }}-15^{\text {th }}$ 2012. Mitteilungen der Prähistorischen Kommission 85. Wien 2016, 115-146.

Demek/Mackovčin 2006 - J. Demek/P. Mackovčin (eds.): Hory a nížiny. Zeměpisný lexikon ČR. Brno 2006.

Dizdar 2015 - M. Dizdar: The Boii and their connections with the Scordisci - Contacts between central Europe and south-eastern Pannonia during the La Tène Culture. In: M. Karwowski/V. Salač/S. Sievers (Hrsg.): Boier zwischen Realität und Fiktion. Akten des internationalen Kolloquiums in Český Krumlov vom 14.-16. 11. 2013. Kolloquien zur Vor- und Frühgeschichte 21. Bonn 2015, 295-308.

Dizdar 2020 - M. Dizdar: Late La Tène bronze fibulae with loops on the foot (fibules à crête). Contacts between Central Europe and the south-eastern Carpathian Basin. In: I. Čižmář/H. Čižmářová/A. Humpolová (eds.): Jantarová stezka v proměnách času. Brno 2020, 559-568.

Filip 1956 - J. Filip: Keltové ve střední Evropě. Praha 1956.

Fischer 1988 - F. Fischer: Südwestdeutschland im letzten Jahrhundert vor Christi Geburt. In: D. Planc (Hrsg.): Archäologie in Württemberg. Ergebnisse und Perspektiven archäologischer Forschung von der Altsteinzeit bis zur Neuzeit. Stuttgart 1988, 235-250.

Holbová 2019 - T. Holbová: Nestandardní polohy s doklady laténských aktivit ve východních Čechách. Archeologie východních Čech 17, 2019, 73-105.

Kysela 2014 - J. Kysela: Okruhy středomořského importu ve střední Evropě pozdní doby laténské. In: Čižmářová/Venclová/Březinová 2014, 229-242.
Mangel 2020 - T. Mangel: Nález laténského vodícího kroužku ze Mšeckých Žehrovic, okr. Rakovník. Archeologie ve středních Čechách 24, 2020, 213-218.

Mangel/Jošková 2019 - T. Mangel/T. Jošková: East Bohemian finds of belt segments with a central knob and side plates as evidence of interregional contacts during the La Tène period. In: N. Beljak Pažinová/ D. Repka (red.): Sedem kruhov Jozefa Bujnu. Studia Historica Nitriensia 23. Supplementum 2. Nitra 2019, 465-480.

DOI: https://doi.org/10.17846/SHN.2019.23.S.465-480

Mangel/Jošková/Krásný 2019 - T. Mangel/T. Jošková/F. Krásný: Nález laténského vodícího kroužku z Markvartic v kontextu obdobných nálezů z Čech a Moravy. Študijné zvesti Aú SAV 66, 2019, 33-48.

DOI: https://doi.org/10.31577/szausav.2019.66.3

Martinek/Golec 2020 - J. Martínek/M. Golec: Dálkové komunikace moravské doby halštatské. In: M. Golec/ P. Fojtík (eds.): Centrum východohalštatské kultury na střední Moravě. Archaeologica Olomucensia 5. Olomouc 2020.

Militký 2015 - J. Militký: Oppidum Hradiště u Stradonic. Komentovaný katalog mincovních nálezů a dokladů mincovní výroby. Praha 2015.

Militký 2018 -J. Militký: Keltské mincovnictví ve 3. a 2. století před Kristem v Čechách. Praha 2018.

Mírová 2019 - Z. Mírová: The Horse in the Bronze and Iron Age in Moravia - Kưň v době bronzové a železné na Moravě. Archaeologica Olomucensia 3. Olomouc 2019.

Mírová 2020 - Z. Mírová: Vưz a koňský postroj v době laténské na Moravě. In: I. Čižmářr/H. Čižmářová/ A. Humpolová (eds.): Jantarová stezka v proměnách času. Brno 2020, 355-383.

Pierrevelcin 2012 - G. Pierrevelcin: Les relations entre la Bohême et la Gaule du IV $V^{e}$ au I Ir siècle avant J.-C. Dissertationes archaeologicae Brunenses/Pragensesque 12. Praha 2012.

Pieta 2008 - K. Pieta: Keltské osídlenie Slovenska. Mladšia doba laténska. Archaeologica Slovaca Monographiae. Studia 11. Nitra 2008.

Řezáč/John 2019 - M. Řezáč/J. John: Mezi Boiohemem a Vindelikem. In: P. Rožmberský/P. Mikota/R. Trnka (eds.): Na stopě (pre)historii jihozápadních Čech 3. Sborník přátel k životnímu jubileu Zdeňka Procházky. Plzeň 2019, 115-123.

Richter 1955 - V. Richter: Prehistorie Moravského Třebovska. Časopis Společnosti prátel starožitností 63, 1955, 141-147.

Rudnicki 2014 - M. Rudnicki 2014: Nowa Cerekwia - the Middle La Tène centre of power north of the Carpathians. In: Čižmářrová/Venclová/Březinová 2014, 421-437.

Rustoiu/Ferencz 2002 - A. Rustoiu/I. V. Ferencz: Piese ornamentale de car din Dacia preromană. Thraco-Dacia 23, 2002, 231-242.

Schönfelder 2002 - M. Schönfelder: Das spätkeltische Wagengrab von Boé. Studien zu Wagen und Wagengräbern der jüngeren Latènezeit. Monographien 54 des RömischGermanischen Zentralmuseums. Mainz 2002.

Skutil 1934 - J. Skutil: Moravská addenda k Paulsenovi. Numismatický časopis československý 10, 1934, 7-23, 165, 167. 
Skutil 1947-1948 - J. Skutil: Z nejdávnější minulosti Litomyšlska a Poličska. Od Trstenické stezky 23, 1947-1948, $14-16,38-48,58-62,75-80$.

Venclová 2008 - N. Venclová (ed.): Archeologie pravěkých Čech 7. Doba laténská. Praha 2008.

Vích 2003 -D. Vích: Laténské nálezy na českomoravském pomezí. Pravěk. Nová řada 13, 2003, 309-350.

Vích 2014 - D. Vích: Pravěk Svitavské brázdy a okolí. In: Čižmářová/Venclová/Břrezinová 2014, 117-132.

Manuscript accepted 21. 6. 2021

Translated by Jan Machula

Mgr. Tomáš Mangel, Ph.D.

Katedra archeologie

Filozofická fakulta

Univerzita Hradec Králové

Rokitanského 62

CZ - 50003 Hradec Králové III

tomas.mangel@uhk.cz
Vích 2017 - D. Vích: Doba laténská v severní části Boskovické brázdy ve světle drobných kovových nálezů. Archeologické rozhledy 69, 2017, 629-671.

Waldhauser 1983 - J. Waldhauser: Závěrečný horizont keltských oppid v Čechách. (Konfrontace výkladů historických pramenů, numismatiky a archeologie.) Slovenská archeológia 31, 1983, 325-356.

PhDr. David Vích

Regionální muzeum ve Vysokém Mýtě

A. V. Šembery 125

CZ - 56601 Vysoké Mýto

dvich@centrum.cz 